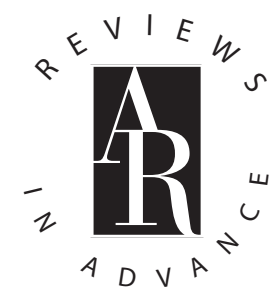

\title{
Corporate Complicity in International Human Rights Violations
}

\author{
Leigh A. Payne ${ }^{1,2}$ and Gabriel Pereira ${ }^{1}$ \\ ${ }^{1}$ Department of Sociology, University of Oxford, Oxford OX1 3UQ, United Kingdom; \\ email: leigh.payne@sant.ox.ac.uk; gabriel.pereira@sociology.ox.ac.uk \\ ${ }^{2}$ Latin American Centre, University of Oxford, Oxford OX2 6JF, United Kingdom
}

Annu. Rev. Law Soc. Sci. 2016. 12:20.1-20.22

The Annual Review of Law and Social Science is online at lawsocsci.annualreviews.org

This article's doi:

10.1146/annurev-lawsocsci-110615-085100

Copyright (c) 2016 by Annual Reviews. All rights reserved

\section{Keywords}

human rights, business, corporations, transitional justice, truth commissions, voluntary principles

\begin{abstract}
Two literatures-business and human rights and transitional justice-can be usefully combined to consider the issue of corporate complicity in past human rights violations in dictatorships and armed conflicts. But although the transitional justice literature emphasizes the positive role that international pressure plays in advancing justice, the business and human rights literature identifies international constraints in the area of corporate abuses. These include the lack of settled law establishing businesses' human rights responsibilities, the absence of courts to adjudicate corporate human rights violation cases, and the international focus on voluntary principles over legal obligations. Despite this unpropitious international climate, civil society mobilization and judicial innovation have advanced accountability efforts and overcome the strong veto power of business in some countries, often creatively blending international and domestic law. These efforts from below provide access to justice for victims and potential models for overcoming the current accountability gap.
\end{abstract}




\section{INTRODUCTION}

Over the past several years, two sets of literatures related to corporate complicity in human rights violations have emerged. One focuses on business and human rights in the current global context. The other examines accountability for corporate complicity in the human rights abuses committed in dictatorships and armed conflicts using transitional justice mechanisms (e.g., truth commissions, trials, reparations). This review holds that the two literatures could be productively connected, providing insights into pathways to reduce corporate abuses and strengthen human rights cultures.

The business and human rights literature places emphasis on international law, courts, and governmental institutions, sometimes recognizing the barriers such factors pose to raising the costs to corporations for committing human rights violations. The international emphasis often overlooks the innovative transitional justice processes carried out in domestic courts around the world driven by civil society mobilization that make corporate human rights violations in past authoritarian regimes or armed conflict situations visible and attempt to hold businesses accountable for those abuses. These domestic-level forces attempt to rescue the universal application of international human rights law and apply it to grave situations of corporate violations.

A multidimensional approach to overcoming impunity for past human rights violations combines domestic and international processes. The four factors identified in this approachinternational pressure, domestic judicial leadership, civil society demand, and weak veto playersthus provide a useful framework for analyzing together the literatures on transitional justice for past corporate human rights violations and business and human rights. After setting out key concepts, the review examines its development through these four factors.

\section{CORPORATE COMPLICITY IN HUMAN RIGHTS VIOLATIONS: LAW AND SOCIAL SCIENCE}

By corporate complicity, we mean businesses' assistance or participation in (aiding and abetting) gross violations of human rights (genocide, torture, crimes against humanity, war crimes) perpetrated by the state or state-like actors (e.g., paramilitary or rebel forces that control territory) during authoritarian or civil conflict situations. Types of corporate acts might include direct complicity in criminal violence (e.g., joint criminal enterprise and conspiracy to violence), violations of human rights under labor law (e.g., slave labor), financing of repression or war crimes, or illegal enterprises (e.g., knowingly procuring or profiting from violence, such as through blood diamonds) (Maassarani 2005, Tófalo 2006). Complicity does not require ideological affinity between corporations and their state or state-like partners. Indeed, corporate entities often defend their actions as a result of extreme pressure rather than willful collaboration.

The social sciences recognize the particular logic surrounding corporate complicity in authoritarian regimes and armed conflicts. The theory of the bureaucratic authoritarian state (O'Donnell 1973) explained the appeal to business of the coups that toppled democratic regimes throughout the Americas and elsewhere and implanted repressive authoritarian systems. Businesses united forces with the military and technocrats to eliminate the perceived communist threat and to advance “capitalist deepening" projects. Businesses' close relationship to the state afforded them protection from the national security system, and they often collaborated with it through blacklists and financing to remove so-called subversive union leaders or workers (Gualde 2013, Payne 1994). In civil conflicts in Africa and Latin America, much of the literature focuses on human rights abuses resulting from business alliances with armed actors over conflict minerals (e.g., blood diamonds) and illegal trade (Reno 1997). Businesses also engage in state or paramilitary "protection rackets" 
(Stanley 1996) to protect their business operations, or profit from the sale of or trade in the tools of repression or war (Avant 2005, Cooper 2002). Banks also find lucrative financing opportunities in repressive or civil conflict systems, particularly when international aid is cut for humanitarian or human rights reasons (Bohoslavsky 2012, Hutto \& Jenkins 2010). The weak or nonexistent rule of law in conflict or authoritarian rule contexts, moreover, means that businesses that abuse do so with impunity (Dandan \& Franzki 2013, Haufler 2010, Reno 1997, Sharp 2013).

Despite widespread knowledge, very few trials for corporate complicity have occurred, and many fewer have found corporations guilty (Payne \& Pereira 2015). Accountability for corporate complicity in authoritarian and civil conflict situations has thus been referred to as the "missing piece of the puzzle, to pursue the full spectrum of justice and remedy for authoritarian and civil conflict periods" (Bohoslavsky \& Opgenhaffen 2010, p. 160). Not surprisingly, Latin America, the leader and innovator in transitional justice, has also become a leader and innovator in efforts around corporate complicity (Hutto \& Jenkins 2010), especially Argentina (Bohoslavsky \& Opgenhaffen 2010; Verbitsky \& Bohoslavsky 2013, 2015; Payne \& Pereira 2015), Chile (Bohoslavsky \& Rulli 2010), Brazil (Bohoslavsky \& Torelly 2014), and Uruguay (Bohoslavsky 2012). To date, however, corporate violations have remained largely "at the periphery of transitional justice work" (Sharp 2014 , p. 2). Social scientists, legal scholars, and practitioners have only begun to consider how to incorporate corporate complicity into the transitional justice framework (Michalowski 2014; Payne \& Pereira 2015; Roht-Arriaza 2013, 2015).

Legal scholars debate the reasons behind the failure to prosecute corporate complicity. For some, the legal responsibility of corporations or their employees in violations under international human rights law constrains accountability efforts. As one scholar stated, "it cannot be said that international human rights law involves direct legal duties for businesses" (Ford 2015, p. 37). Yet for others, corporate complicity has been "legitimized and incorporated into the fabric of international law" (Skinner 2008, pp. 356-57). The plethora of studies and debates in legal scholarship exists in large part due to the need for legal interpretation in the absence of settled international law.

The business and human rights literature incorporates into the debate over international law the question of compliance by firms and enforcement by states. The political economy of business and human rights suggests that states are less likely to sanction businesses for abusive behavior in industries integral to the national economy or national security (Ite 2004, Madami 1999, Moran 2002). States may fear that companies threatened with judicial action may relocate to more permissive investment environments (Dougherty 2011). They may also fear the repercussions for foreign investment if they are perceived as hostile to business and foreign investment. Recognizing these constraints, some scholarship has considered persuasion and low-cost mechanisms as a safer pathway than trials to enhance corporate compliance to international human rights standards (Balmer et al. 2011, Buhman 2013, Laufer 2003). Other scholars contend that only when violations are perceived by businesses to increase production costs or reduce profits will they comply with global human rights norms (Deitelhoff et al. 2010, Porter \& Kramer 2006, Wolf et al. 2007).

Combining these social science and law approaches to explain the failure to hold corporations accountable for human rights violations resembles the four-factor multidimensional approach (Payne et al. 2015). In that approach, international pressure, domestic judicial leadership, civil society demand, and weak veto players are necessary to overcome impunity for human rights violations. The framework provides a useful explanation for continued impunity identified in the literature. Drawing from legal scholarship, the absence of settled international law on corporate complicity limits international pressure for accountability. Not only do domestic judicial institutions feel little international pressure, they cannot draw on settled international law or judicial 
action to advance cases in local courts. Civil society advocates also focus more on state violations than those carried out by nonstate actors as a more effective and well-established area of mobilization. Finally, owing to its global and domestic power, identified in the business and human rights literature, business plays a powerful veto role in the development and implementation of accountability for corporate complicity. How the literature has examined these four factors is further elaborated below.

\section{INTERNATIONAL PRESSURE FOR CORPORATE ACCOUNTABILITY}

The concept of transitional justice emerged from the Nuremberg Trials and their value in holding state leaders accountable, redressing wrongs, and advocating for the "never again" of mass atrocity (Teitel 2000). Transitional justice has not yet incorporated the lessons from the other set of Allied trials, the so-called industrialist cases. US, UK, and French tribunals tried over 40 businessmen for forced or slave labor, plunder of Jewish properties, and financing or assisting in mass extermination. The Allied forces believed that the Third Reich, its aggressive war, and its concentration camp atrocities would not have been possible without corporate complicity. Trials thus provided the means to address victims' rights and condemn corporate violations to prevent them in the future.

Scholars have debated the industrialist cases' legacy in contemporary corporate complicity accountability efforts. One group of scholars considers the industrialist cases inapplicable to subsequent contexts due to the incomparable atrocities in which businesses engaged in Nazi Germany. Some argue that even in this case acquittals resulted from the inability of the prosecution to prove individuals' knowledge of the mass extermination or their contribution to "aggressive war" (Danner 2005). Others argue in contrast that the legacy of the industrialist cases is evident in the legal doctrine in regional human rights treaties and in the arguments and decisions presented in contemporary corporate complicity cases (Skinner 2008).

If this legacy existed, it would be found in international pressure for accountability for corporate complicity. Yet little evidence supports such a view. In contrast, and consistent with the notion of "transnationalism reversed" (Friedman 1999), international pressure measured in terms of the normative legal framework and its application to civil and criminal cases could be said to have had a negative impact on domestic accountability efforts. Such an impact is surprising given the effective international pressure in bringing accountability for heads of state for past human rights violations (Davis 2003, Lutz \& Reiger 2009, Roht-Arriaza 2005, Sikkink 2011). The negative effect of international pressure on business responsibility or past human rights abuses seems to result, at least in part, from the unsettled nature of this area of international law. That in turn may result from relatively powerful business veto players active in international and domestic governmental and legal arenas.

\section{Corporate Complicity and International Norms}

International pressure on business and international human rights norms currently involves an emphasis on soft-law and voluntary principles (Ruggie 2013) rather than binding and enforceable obligations. This approach is widely criticized for signaling to states and businesses that corporate obligations under international human rights law are voluntary. For these reasons, critics accuse the normative approach to business and human rights as failing to promote strong international pressure for accountability.

The evolution toward the current state of business and human rights norms has been well documented (Bilchitz \& Deva 2013, Mantilla 2009, Martin \& Bravo 2016, Popova 2016). 
Chronologically, the 1970s is characterized by self-regulation through corporate social responsibility initiatives (Sagafi-Nejad \& Dunning 2008). These firm-level initiatives may have responded to, or indirectly contributed to, a vague global norm regarding corporate respect for international human rights that made its way into various institutional bodies. ${ }^{1}$ In the 1980s and 1990s, in the wake of several disasters in which businesses were involved, efforts to control abusive firms and salvage industries' reputations emerged (Haufler 2010, Wawryk 2003). ${ }^{2}$ Although these industry sector-led initiatives indicated that companies might accept monitoring and enforcement of global human rights standards, and human rights advocates pushed for such global agreements, voluntary measures prevailed.

The most significant developments toward establishing global standards for corporate complicity came with the 1999 United Nations (UN) Global Compact and the 2003 UN Draft Norms on the Responsibilities of Transnational Corporations and Other Business Enterprises with Regard to Human Rights (the so-called Norms). The Global Compact calls on "companies to align strategies and operations with universal principles on human rights" (http://www. unglobalcompact.org/what-is-gc). It claims adherence in nearly every country of the world and among $60 \%$ of the world's largest businesses (Mwangi et al. 2013, p. 207). The Norms emphasized universal human rights and responsibilities that included businesses' binding and enforceable obligations to "promote, secure the fulfillment of, respect, ensure respect of, and protect human rights." UN member states and business stakeholders rejected the binding nature of the Norms. The controversy that ensued led the UN to abandon them (Mantilla 2009), thereby missing an opportunity to create international pressure around accountability for corporate complicity.

Instead, the UN Commission on Human Rights (later the Human Rights Council) unanimously endorsed the 2011 Guiding Principles on Business and Human Rights (hereafter the Guiding Principles). Unlike the Norms, the Guiding Principles, drafted by Special Representative John Ruggie, received widespread support from international governmental organizations, states, and businesses (Ruggie 2013, p. xxi). Like the Norms, they explicitly recognize businesses' responsibility to respect human rights. In contrast to the Norms, however, the Guiding Principles depend on voluntary adherence and soft law, rather than enforceable and binding obligations, to guide businesses' human rights behavior.

Human rights practitioners and legal scholars widely criticize the Guiding Principles. Even when these critics accept that soft law might have been the only, or most effective, way to reach agreement on corporate human rights duties, they still call on the Guiding Principles to clarify the specific obligations and standards states and businesses must follow to comply with international human rights law (Horrigan 2010). As Paul \& Schönsteiner (2013, p. 74) point out, the Guiding Principles had the opposite effect by producing "sometimes inaccurate representations of international law regarding certain aspects of states' obligation to protect; the lack of clarity on some aspects of the substantive dimension of the corporate responsibility to respect; and the absence of recommendations for effective enforcement mechanisms and of limits set for private reparations initiatives." Horrigan refers to the voluntary and soft-law nature of the

\footnotetext{
${ }^{1}$ These include the UN's Center on Transnational Corporations (1974), the Organization of Economic Cooperation and Development's Declaration on Decisions on International Investment and Multinational Enterprises and its Guidelines for Multinational Enterprises (1976), and the International Labor Organization's Tripartite Declaration of Principles Concerning Multinational Enterprises and Social Policy (1977). Perhaps the best known of these initiatives are the Sullivan Principles on Apartheid and the US Foreign Corrupt Practices Act—both adopted in 1977.

${ }^{2}$ These include the Chemical Manufacturers Association's Responsible Care Program (1984) after Bhopal; the Fair Labor Association's (1998) response to Nike's sweatshop practices; and the Kimberley Process Diamond Certification Scheme (2002) and the Extractive Industries Transparency Initiative (2003) in response to conflict minerals.
} 
application of international law to the private sector as a weak form of accountability (Horrigan 2010, p. 325).

Other scholars go further in their criticisms of the Guiding Principles. By failing to raise the cost to corporations of committing human rights violations, the Guiding Principles fail to deter abuses (Weissbrodt \& Kruger 2005). Businesses can cynically adopt or sign onto corporate social responsibility, industry-led, and Global Compact-Guiding Principles initiatives without any intention of changing behavior. Indeed, consistent with some of the treaty compliance literature (Hathaway 2002, Neumayer 2005), signing on to these global initiatives may provide the necessary cover for businesses to continue or increase human rights abuses. These scholars view reliance on soft-law and voluntary principles as unlikely to guarantee improvements in corporate human rights behavior and advocate instead attaching tangible costs to corporate human rights abuses.

Social science deterrence theory would concur with these claims in legal scholarship. That theoretical approach assumes that tangible costs associated with behaviors will likely change them (Bueno de Mesquita \& Cohen 1995, Downs et al. 1996, McCarthy 2002, Nagin 1998). Deterrence theory would suggest therefore that the credible threat of judicial action against firms that commit abuses would signal to the business community the heightened cost of human rights violations, thus curbing such behavior.

Very few empirical studies test the effectiveness of voluntary principles. Those that do seem to concur that such mechanisms are insufficient to bring human rights improvements. Lim \& Tsutsui (2012) find "organized hypocrisy," and not a deep commitment to human rights obligations, among the 99 firms they study that have signed onto the Global Compact. Two studies that use Olsen and Payne's Corporate Human Rights Database (http://www.chrdproject.com) find voluntary principles insufficient in remedying or redressing business human rights abuses. In her study on Peru, Babineau (2015) found that Global Compact signatories were just as likely as businesses who did not sign on to be accused of human rights violations; they were, moreover, equally unlikely to remedy violations. Pressure from the government, and not voluntary principles, seemed to promote companies' positive human rights behavior. Bernal-Bermúdez (2016) also found few human rights behavioral differences among firms in Colombia that signed onto voluntary principles compared with those that had not. Both statistical and qualitative case study analysis pointed to pressure from transnational advocacy networks (Keck \& Sikkink 1998) for positive human rights outcomes. In summarizing these empirical findings, at best voluntary principles have done little to diffuse understanding of business obligations under international human rights law. At worst, they signal to businesses and states that these obligations are voluntary, thereby undermining efforts to strengthen global human rights protections.

The global community has recognized the limited, if not negative, outcome of reliance on voluntary principles to improve corporate human rights behavior. Perhaps as a response, the UN Human Rights Council initiated in 2014 a process to elaborate a legally binding instrument on transnational corporations and other business enterprises in respect of human rights. In its resolution 26/9 it created an open-ended intergovernmental working group and a process of intergovernmental negotiations in several phases. No blueprint has yet emerged from the first meeting of the working group in June 2015 and subsequent follow-up processes.

This initiative, and the slow evolution to reach it, may reflect the creation of norm bandwagons or norm cascades (Sunstein 1996) that can lead to international pressure for corporate human rights accountability. At present, however, the voluntary and soft-law principles may undermine civil society mobilization and domestic judiciaries' efforts at promoting corporate accountability. International pressure is further compromised by the unsettled state of international law on corporate accountability for human rights abuses. 


\section{Corporate Complicity and International Law}

International pressure on states to comply with human rights obligations has proved instrumental in holding perpetrators of human rights violations accountable in the aftermath of dictatorships and armed conflict even where amnesty laws protected them (Payne et al. 2015). In the case of corporate complicity, however, impunity persists. The unsettled nature of international law on corporate complicity seems to obstruct international pressure for accountability on the questions of (a) criminal liability of corporations, $(b)$ corporate criminal acts, $(c)$ territorial jurisdiction, and (d) effectiveness of trials.

Some scholars contend that no international forum recognizes the criminal liability of a company entity (Clapham 2008, Int. Comm. Jurists 2008, Nolan 2013, van der Wilt 2013). The Rome Statute of the International Criminal Court (ICC) and the Statutes of the ad hoc International Criminal Tribunals for the former Yugoslavia (ICTY) and Rwanda (ICTR) have provisions that unequivocally declare that these tribunals have jurisdiction only over natural persons. Where these courts have heard corporate complicity cases, individual employees and not the companies have faced accountability. This is the case for ICTR's media case (Ferdinand Nahimana and JeanBosco Barayagwiza of Radio Télévision Libre des Mille Collines; Hassan Ngeze of the Kangura newsletter), the Mugonero incident trial (Elizaphan and Gérard Ntakirutimana), and the Gisovu Tea Factory trial (Alfred Musema).

The failure to recognize corporate criminal liability for grave human rights violations limits corporate accountability. Businesses argue that they are not bound by international criminal law that is aimed at individuals or international human rights law aimed at states. This argument does not hold up in all states, however. Variation exists across countries with regard to corporate criminal liability (van der Wilt 2013; Zerk 2014, p. 32), suggesting that the law that protects companies from criminal responsibility may be less settled than assumed.

Moreover, strategies are under way to overcome this restriction on accountability at the ICC. ${ }^{3}$ Kelly (2012, p. 363), for example, proposes reform of the Rome Statute to include jurisdiction over corporations. He claims that exclusion of such jurisdiction from the Rome Statute was not due to "a coordinated effort motivated by overt hostility to the notion of holding companies accountable." His review of the preparatory conference suggests that time constraints, and not legal principles, failed to establish jurisdiction over corporations in the final statute. The necessary "legal impetus and political cover" to amend the treaty, he contends, could be provided by the International Court of Justice (ICJ). If the UN General Assembly were to ask the ICJ whether corporations can be prosecuted for genocide, for example, and the ICJ were to answer in the affirmative, then this restriction on corporate accountability could be removed by amending the statute. ${ }^{4}$

For some scholars, the restriction on corporate criminal liability in international law is not necessarily an impediment to accountability. Referring to the post-World War II industrialist cases, only individual executives, and not corporations, were held accountable. Nonetheless, Skinner $(2008$, p. 344) contends that the trials support the "decision that corporations are bound by international law and thus liable for human rights violations" (Skinner 2008, p. 344). As an example, Skinner (2008, p. 345) states that although "individuals were nominally on trial, the Krupp company itself, acting through its employees, violated international law." The individuals named

\footnotetext{
${ }^{3}$ Proposals to extend the jurisdiction of the ICC to cover corporate entities were on the agenda of the Kampala Review Conference in 2010, but, according to van der Wilt (2013, p. 45), they were overshadowed by the preoccupation with the crime of aggression and hence not properly discussed. See also Heyer (2012) and Clapham (2000).

${ }^{4}$ According to Kelly, the ICJ may issue advisory opinions - and has done so at the request of the General Assembly at least 15 times-when requested to do so by organs or approved agencies of the United Nations.
} 
in the industrialist cases "were acting within the scope of their employment or pursuant to their employment" (Skinner 2008, p. 364) and not as individual or independent citizens. Van der Wilt (2013) seems to agree when he argues that the position of power and knowledge required for a corporate agent to incur criminal responsibility for international crimes corresponds to that agent's internal position within the corporation that thus criminally implicates the corporate entity. ${ }^{5}$

Disagreement among legal scholars over corporate liability in human rights crimes is further evident in works by Schabas (2005) and Kelly (2012). Elaborating on international criminal case law, including the industrialist cases mentioned above, Kelly affirms that corporations are subjects of international law in general, and the Genocide Convention in particular, and that they are capable of forming both general intent and specific intent required to prosecute for genocide. These multiple and contradictory interpretations of corporate criminal liability indicate the unsettled nature of international law. They further illustrate the difficulty of developing unequivocal international pressure in favor of accountability for corporate abuses.

A second constraint on international pressure for accountability is the definition of corporate criminal acts. From the industrialist cases, scholars claim that "when corporations assist states [or state-like forces] that engage in human rights abuses... [they violate] the prohibition against aiding and abetting war crimes and other human rights violations... recognized as customary international law" (Skinner 2008, p. 351). Despite the vagueness of this language, the industrialist cases did not all end in "victors' justice." Defendants were convicted or acquitted and received varying sentences based on mens rea criteria or the likelihood that they would have known that their acts contributed to war crimes or crimes against humanity. Vest (2010, p. 853) establishes a twofold test to link corporations' provision of materials, goods, or services to the perpetration of an international crime. Proximity of business conduct and adaptation of that business conduct to criminal acts by the state (or state-like actors) constitute the first measure. Second, it must be shown that the business conduct occurred with the knowledge of its contribution to an international crime carried out by the state (or state-like actors). Corporate complicity in an international crime involves knowledge of the specific criminal use of the business's products, acts, or services.

Successfully proving an individual employee's knowledge of the company's complicity in a state or state-like actor's criminal act in the post-Nuremberg era is rare. One example is the case of Frans van Anraat, who was accused of complicity in war crimes and genocide for selling a mustard gas component used against civilians in Iraq and Iran by Saddam Hussein's regime. The court of appeals determined that the prosecution could not prove the accused's intent to commit genocide. Nonetheless, the court found evidence of the defendant's knowledge that the component "would serve as a precursor for mustard gas" compelling. This knowledge was sufficient to satisfy the mens rea element of the charge of complicity to commit war crimes.

The example shows that widespread agreement exists on the knowledge and type of criminal act that constitute corporate complicity. Variation exists in different courts and in different criminal law systems, however, over the degree of proof necessary to establish knowledge of, or intent to participate in, a criminal act (Zerk 2014, p. 38). Different legal requirements in domestic and international courts lead to weak international pressure over when and how to hold corporations accountable for human rights violations.

Jurisdictional variations pose a third barrier to international pressure. Given the lack of settled international law over corporate complicity, courts vary widely on their decision to hear or dismiss

\footnotetext{
${ }^{5}$ The author builds his arguments on the French proposal on corporate criminal liability, presented during the drafting process of the Rome Statute, as a preliminary normative framework. He tests his arguments analyzing case law of both domestic and international criminal courts in which individual business leaders faced trial on charges of complicity in international crimes.
} 
cases. For example, arguments made by parent companies that they have no responsibility for subsidiaries' acts may hold in certain courts and not in others. The opposite is also argued: The lawyers for Chevron in Chevron Corp. v. Naranjo challenged Ecuador's jurisdiction over the USbased company's Ecuadorean subsidiary (TexPet) on territorial and legal responsibility grounds.

The legal complexity of corporate complicity cases results in part from the lack of settled law. It further contributes to the difficulty in winning corporate complicity cases in international, foreign, and domestic civil or criminal courts. In building a database of cases of corporate complicity, we found only 61 corporate complicity cases in any court: international criminal (1), foreign criminal (4) or civil (33), and domestic criminal (17) or civil (6) trials. ${ }^{6}$ Of those cases that we found, very few have ended in a final court decision. Most cases remain ongoing or under appeal, were dismissed, or settled before reaching final judgment. Although we could not find a systematic study of the outcome of the industrialist cases despite the decades of research, we know that not all of the 40 defendants were prosecuted or found guilty. Moreover, in 1951 the US High Commissioner for Germany granted clemency to, released from prison, and returned assets to many of those convicted and imprisoned in Germany by US tribunals (Wiesen 2000). In one analysis by Kelly (2012), the 60 civil cases of corporate complicity brought under the Alien Torts Statute (ATS) in US courts ended without legal victories for the plaintiffs. Cases were dismissed or companies settled before a final judgment (and on the condition of no admission of wrongdoing). Even these limited advances in terms of judicial outcome (Stephens 2000) may have been further compromised in the aftermath of the US Supreme Court's 2013 Kiobel decision. Scholars and practitioners assume that this tool for accountability has been eviscerated (Alford 2014). With these inconclusive outcomes for corporate complicity cases brought in international, foreign, or domestic courts, strong international pressure for accountability has failed to materialize.

In sum, human rights norms' convergence and international human rights laws and institutions have arguably had a "cascading effect" on holding heads of state accountable for past human rights violations (Sikkink 2011). The same cannot be said for international norms or legal pressure for corporate accountability for human rights violations. International pressure is constrained by unsettled law, legal complexity, and inconclusive outcomes. Some evidence even points to receding opportunities for international pressure for accountability rather than expanding ones. Rather than a spiraling effect that enhances human rights norms and practices through the diffusion of global accountability norms (Risse \& Ropp 2013), global efforts seem to be trending toward greater barriers to bringing cases, fewer accountability mechanisms, less global accountability, and greater emphasis on self- or industry regulation and voluntary measures within the business community.

A longer-term look might prove less pessimistic about the future of international pressure. The debate over corporate complicity is relatively new. As one scholar contends, "Prior to the mid1970s, there was little international attention to the role of corporations in human rights abuses" (Skinner 2008, p. 366). Moreover, the barriers presented here could constitute the very making of settled law from which international pressure for accountability might emerge (Wouters \& Ryngaert 2009). Halliday \& Carruthers (2007) and Liu \& Halliday (2009) identify indeterminacy of law, contradictions, diagnostic struggles, and actor mismatch as processes that potentially lead to settling, and could be applied to settling international human rights law (Payne 2014). Thus, with time and continued contestation we may see settled law and corresponding international pressure in favor of accountability.

\footnotetext{
${ }^{6}$ We continue to find additional cases, however. For example, see Stewart (2014) for a discussion of ongoing criminal cases in
} Swiss courts. 


\section{DOMESTIC JUDICIAL INITIATIVES}

Despite the equivocal or negative international pressure for corporate accountability, domestic judiciaries have taken some important initiatives, often developing innovative legal strategies that might be adapted to other legal systems (Joseph 2000). These innovations creatively combine domestic law and international human rights law.

Creativity may emerge in the context of extreme adversity. Prosecutors face particular legal and procedural difficulties in establishing businesses' responsibility. Among the most relevant ones, Zerk (2014) highlights the following: the difficulty of identifying the appropriate entity or entities against which to lodge a private law claim in cases involving large transnational groups of companies; objections to lawsuits based on doctrines of sovereign immunity, "act of State," and "political question" frequently encountered by claimants in ATS cases; the nonapplicability of criminal law provisions to corporate entities in some jurisdictions; and the existence of rules that place restrictions on the ability of individual victims, their representatives, and other organizations (e.g., nongovernmental organizations) to initiate and participate in legal proceedings. She also includes practical obstacles blocking accountability in domestic courts, including but not limited to scarce availability (or nonavailability) of legal aid, "loser pays" rules, and lack of resources and specialized expertise within prosecution bodies.

Along with these general challenges to the implementation of corporate accountability at the domestic level, the difficulty of establishing the legal person who could represent the corporation's complicity in human rights accountability has posed obstacles in advancing cases. Due to the time passed since dictatorships or the beginning of conflicts, those most responsible for corporate decisions have died, left the company and the country, and in other ways are difficult to track down and prosecute. Similarly, records directly implicating the company or the individual rarely exist, particularly when the firm becomes aware of a pending lawsuit.

The barriers to domestic prosecution are, in sum, huge. But they are not insurmountable. Four domestic cases presented below (three from Argentina and one from Colombia) provide illustrations for how prosecutors can, and have, overcome these barriers to accountability. The creative strategies used might provide translatable and transportable models for corporate accountability in postdictatorship and post-armed conflict situations.

Two cases-Ingegnieros (Cámara Nacional de Apelaciones del Trabajo, 2012, Ingegnieros María Gimena c. Techint S.A, Compania Técnica Internacional, 73797) and Siderca (Corte Suprema de la Provincia de Buenos Aires, 2007, Cebrymsky, Ana María c. Siderca S.A.)—creatively combined claims under Argentina's labor law and international human rights law to win compensation from companies to families for the disappearance of workers. In February 2012, in the Ingegnieros case, an appeals labor court dismissed the statute of limitations claims of a legal action brought to the court. María Gimena Ingegnieros, the daughter of Enrique Roberto Ingegnieros, brought the case. She requested financial compensation for her father's disappearance during the civil-military dictatorship. She claimed that Techint SA, owing to its coauthorship of the crime of disappearance on the company's grounds, should pay compensation. The company denied the claim and argued that the two-year statute of limitations on worker safety had long since run out. The appeals court rejected the company's argument, declaring that statutes of limitations do not apply to compensation claims linked to crimes against humanity. The family was awarded compensation in this innovative combination of domestic labor law and international human rights law. ${ }^{7}$

The April 2007 Siderca case, brought by Ana María Cebrymsky, the wife of Oscar Orlando Bordisso, and heard by the Supreme Court of the Province of Buenos Aires, follows a similar logic.

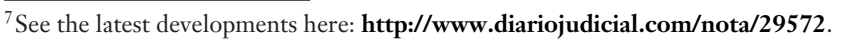


Bordisso disappeared shortly after he left work one day in 1977. In 1995, his wife claimed compensation from his employer-Siderca—under Argentine labor law, specifically, that the country's work safety law obliged the company to protect her husband on entering and exiting the work site. The company rejected the claim and argued against legal action owing to the statute of limitations. The first-instance tribunal accepted the claim against the company. On appeal, the company again lost in the Provincial Supreme Court. The court ordered compensation for Bordisso's widow.

These cases illustrate a creative blending of domestic labor law and international human rights law to recognize companies' duties to respect and protect human rights and to remedy abuses. Neither case relied on international ruling but instead demonstrated the significance of domestic judicial leadership in linking domestic and international law. Without that leadership and innovative strategy, these cases would have been easily dismissed for falling outside the statute of limitations in worker safety cases. Although tried in civil courts, the use of international law recognizes the crime against humanity, the responsibility of the firm in committing such a crime, and the duty to provide some form of reparations for the victims' families. Families of workers murdered or disappeared due to authoritarian states or armed conflict could adapt this innovative linkage of labor law to crimes against humanity to seek accountability and remedy where criminal trials with evidentiary constraints face obstacles.

Another innovative example from Argentina is the Vildoza case (Juzgado Nacional en lo Criminal y Correccional Federal No 12, Vildoza, forge Raúl \& otros - Delito de Acción Pública Case No 13.340/08). Several military officers and civilians were accused of the illegal procurement of property from individuals detained by the dictatorship's repressive apparatus and the sale of the real estate to private individuals and companies connected to the military. The investigation was initiated by the public prosecutor and private partners and later included the Financial Information Unit (Unidad de Información Financiera), the state agency in charge of investigating moneylaundering activities. The case has hinged on the controversial ruling that the money-laundering law initiated in 2004 could apply to an incident from the 1970s. The court agreed to hear the case after accepting the argument that the profit from the sale of the real estate transaction continues to benefit the individuals who initially seized the property. The case is ongoing.

The Urapalma case (Juzgado Quinto Penal del Circuito Especializado de Medellin, octubre 30, 2014, Ruling No. 054, 0500131070052011 01799) is the first criminal conviction in Colombia of businessmen for their role in the forced displacement of communities by paramilitary forces during the armed conflict. Several of the palm oil company's executives and former employees were convicted in October 2014 and are in prison for their links to paramilitary groups in the forced displacement of Afro-Colombian communities. Some are expected to serve up to 10 years in prison and face fines of 2,650 minimum wages. Regarding remedy, the Court ordered the defendants to pay compensation of approximately 20 million pesos (approximately $\$ 7,000$ ) to each victim of forced displacement and ordered several state entities to guarantee and monitor the process of restitution of lands to the communities. The case expanded the legal scope of the crime of forced displacement to enable conviction of company employees and recognized the rights of internally displaced people to return to lands occupied by private actors.

These cases show that legal innovations at the domestic level are emerging. They bypass the constraints on accountability emanating from the international focus on soft-law and voluntary principles. They have applied domestic laws, often in combination with international human rights law, to reach judgments against corporate acts. Most of the successful outcomes of the domestic cases that we have found globally involve civil courts; successful criminal actions are much rarer.

That these cases have begun to develop case law and legal strategies suggests that domestic processes in this area may be a more appropriate focus than an international one. The diffusion of norms and practices from the international sphere-specifically, the reliance on soft-law and 
voluntary principles-may have a deleterious effect on domestic prosecution, in contrast to the processes against state actors. Domestic processes have the potential of diffusing across borders, creating a cumulative effect in which businesses become less and less likely-like the heads of state before them-to evade responsibility for their past acts.

\section{CIVIL SOCIETY DEMAND}

Civil society mobilization has the potential to change corporate human rights behavior (Addo \& Martin 2016, Narine 2016), but has thus far lagged behind demand for accountability for state perpetrators. Traditionally, human rights and victims' groups have focused on states' failure to "protect, respect, and remedy" human rights (Ruggie 2014). International law has not yet developed settled law for holding businesses to the same standard. Although there is consensus within and outside the business community regarding firms' "responsibility to refrain from harming human rights" (Karp 2014, p. 63), "there is as yet no customary international law norm on the extent of corporate responsibility for human rights violations ... and an enormous diversity in national laws on these issues" (Ford 2015, p. 37). Civil society mobilization is partly constrained in its mobilization by its traditional orientation toward states and the unsettled nature of international law in the matter of corporate complicity. The post-Kiobel environment may pose even more constraints on civil society mobilization.

The limitations on judicial action may indicate that "naming and shaming," or concerted global campaigns (Felstiner et al. 1981), will prove more effective in increasing costs, at least reputational ones, for corporate complicity. Widespread attention through traditional and new social media to corporate complicity, public condemnation, visible protests and denunciations, and the threat of prosecutorial activity may prove as effective as, if not more effective than, trials themselves in communicating norms and dictating corporate behavior. Building on the normative socialization approach (Sunstein 1996), such civil society actions may motivate corporate responses to offset negative reputational or potential prosecutorial costs.

Civil society mobilization through truth commissions offers a potentially significant "naming and shaming" function. A study reveals that 23 out of 27 countries' truth commissions acknowledge corporate complicity in human rights violations, and most of those name specific companies responsible for abuses, with around 250 companies named (Payne \& Pereira 2016). ${ }^{8}$ Truth commissions potentially raise visibility of corporate complicity; raise costs to specific firms identified; and hold those companies accountable publicly, if not legally.

Argentina provides an example. The earliest truth commission for human rights violations in the world, the 1983 National Commission on Disappeared Peoples, identified 10 specific companies by name for violating human rights as part of the dictatorship's system of repression. In the subsequent anniversaries of the coup, civil society groups condemned corporate complicity. In the 2015 anniversary, for example, graffiti, posters, and speeches asked rhetorically whether the public supported "democracy or corporations." As a result of the visibility of corporate complicity, references to the "military dictatorship" changed to the "civil-military dictatorship" to reflect the role of corporations in repression. ${ }^{9}$ That Argentina is the country with the highest number of judicial cases for corporate complicity globally (Payne \& Pereira 2015) may reflect the evolution from civil society "naming and shaming" campaigns to prosecutorial activity.

\footnotetext{
${ }^{8}$ We have identified a total of 50 possible truth commission reports to review. We have failed to gain access to the final reports of an additional 12 commissions.

${ }^{9}$ Similar renaming of the past political regimes occurred in Brazil and Uruguay for the same reasons.
} 
The well-known and highly revered South African Truth and Reconciliation Commission (TRC) also recognized corporate complicity in the Apartheid regime's human rights abuses. The TRC held special hearings on business and carefully documented in its final report the benefits the corporate community received from, as well as its financing of and contribution to, the Apartheid regime's violence. The TRC concluded that a strong legal case against businesses could be made under international law. The TRC was one of only a small number (nine) of truth commissions that made specific recommendations regarding corporate complicity. The recommendations did not include prosecution, but rather a wealth tax, a single levy on corporate and private income, a donation by each company listed in the Johannesburg Stock Exchange in the amount of 1\% of its market capitalization, a retrospective surcharge on corporate profits during the Apartheid era, and a reconsideration of paying Apartheid-era debt. In addition, individual members of the business community were asked to voluntarily contribute to reparations and development in the post-Apartheid era (Colvin 2006, p. 199).

Those recommendations did not advance very far. South African president Thabo Mbeki rejected the call for a wealth tax or other forms of reparations from the private sector. The social movement Jubilee South Africa highlighted the role that multinational corporations played in repatriating profits outside South Africa and sought, without success, both debt relief and reparations from these businesses. A business trust was built on a 1.2 billion rand donation from 140 business groups and the post-Apartheid government. The trust fails, however, to make any connection to corporate complicity in the Apartheid era or companies' moral obligation to contribute to the new South Africa or to compensate victims in light of past corporate abuse (http://www.btrust.org.za/partners.html). Colvin's (2006, p. 205) study of South African reparations concludes that "the culpability of domestic business has also not been seriously considered. Business either ignores the question or makes absurd offers to 'manage' the disbursement of reparations funds."

Frustrated at the unwillingness of the government to hold business to account, the Khulumani Support Group used ATS to file a lawsuit (Khulumani v. Barclay National Bank Ltd.) against key international companies in a New York court. The civil suit sought compensation from those who had invested in, and profited from, the discriminatory policies of the Apartheid era, including job reservation, wage discrimination, and forced labor. The Mbeki government actively sought to undermine the lawsuit. Minister of Trade and Industry Alec Erwin claimed that the government would not enforce judgments made by the New York court (Thompson 2013). Minister of Justice Penuel Maduna attempted to have the case dismissed owing to its interference in South Africa's domestic process and state sovereignty. These combined actions were interpreted as efforts to reassure the business community of a positive investment climate (http://truth.wwl.wits.ac.za/cat_descr.php?cat = 4).

Undeterred, South African civil society has continued to fight in US courts and in South Africa. During the 2010 Soccer World Cup, for example, Khulumani initiated campaigns against some of the corporations in the lawsuit. As the "Red Card" campaign stated, "Daimler AG generously sponsored the German team in its quest to win the Soccer World Cup on South African soil, while ignoring calls to acknowledge and pay reparations for its 'sponsorship' of apartheid atrocities." The campaign involved posters identifying Daimler's Mercedes Benz iconic hood ornament as the "star of Apartheid" (Red Card Campaign 2010). The nongovernmental organization Open Secrets has also engaged in research and public exposure of the linkages between contemporary corruption and violent and illicit businesses with the Apartheid era (http://www.opensecrets.org.za).

Although Brazil compares poorly with Argentina and South Africa in terms of transitional justice accountability mechanisms, it has recently advanced beyond other countries in the area of corporate complicity in the dictatorship (Bohoslavsky \& Torelly 2014). Civil society actors 
have taken the lead in these endeavors. Mobilization around the National and São Paulo State Truth Commissions could be said to have acted as a catalyst to investigate the role that corporations played in the 1964 coup and subsequent dictatorship. Those investigations and parallel civil society activities led to public acts to reveal complicity. In one such act, students mobilized to petition for the removal of a São Paulo street name associated with one of the businessmen connected to the coup and repression. A video of their activities (Brant 2013), as well as a film about the businessman, circulated widely on YouTube (Payne 2013). The Truth Commission and civil society pressure for accountability are considered to be crucial to the opening up of the lawsuit against Volkswagen for its role in the dictatorship's repressive apparatus (Boadle \& Winter 2014). No international pressure is behind this judicial action.

Although these civil society initiatives mark a new shift toward corporate accountability for human rights violations, they remain scarce. They attract some local and international attention when they occur. But their capacity to promote "bottom-up" approaches (Černič 2016, Levit 2007) remains largely blocked thus far by the power of business.

\section{CORPORATE VETO POWER}

The veto power of business is thus crucial to understanding the limitations on corporate accountability for human rights violations. An extensive literature exists in the social sciences on the political, economic, and social power of business elites and their capacity to influence states and societies. ${ }^{10}$ It also recognizes limitations on corporate power, particularly fragmentation that impedes collective action.

The business and human rights literature overlooks these limitations on power, focusing instead on the global might of a few companies that enables them to influence domestic and international processes. That "the largest multinationals now dwarf the economies of many countries and frequently mobilize greater political influence" (Chesterman 2004, p. 307) suggests that some corporations may not need collective action to leverage veto power over decisions made in the international, foreign, or domestic arena.

Corporate direct action, moreover, may not be necessary to veto power. Mills (1956) might contend that by comprising the "power elite" along with judges, prosecutors, and politicians, business leaders are guaranteed protection from corporate accountability. The lack of settled law on corporate human rights obligations creates a legal and moral space in which certain shared values within the power elite produce favorable results for business.

Implicit veto power may also result from recognition of dependence on business for global or domestic economic stability and well-being. Such recognition may result in an unwillingness to sanction abusive behavior (Ite 2004). Firms in strategic sectors of the global or domestic economy may enjoy fewer constraints on their behavior than firms in less critical sectors (Madami 1999, Moran 2002). States may avoid hearing, investigating, or enforcing human rights standards if they anticipate repercussions of appearing hostile to business, such as loss in foreign investment or business relocation to more permissive investment environments (Dougherty 2011).

Business veto power over accountability emanating from wealth, shared values and beliefs, and dependence is not easily proven. Nonetheless, certain patterns of behavior have been identified in the literature. Possessing extensive financial resources, corporations have more capacity than most victims of abuse to hire high-priced, skilled lawyers to defend them in complicated legal battles.

${ }^{10}$ See, for example, Block 1984; Lindblom 1977; Miliband 1969; Mills 1956; Offe \& Wiesenthal 1980; Poulantzas 1968; Skocpol \& Somers 1980; Vogel 1978, 1983. See also Payne 1994, pp. 1-15, for a review of this literature. 
Hearings to dismiss the case or to clarify legal technicalities, and the lengthy trials and appeals processes, incur costs more easily absorbed by the corporate defendants than the victim plaintiffs (Zerk 2014). Businesses tend to offer financial settlement when they anticipate legal defeat on the condition of no acknowledgment of wrongdoing. These settlements avoid what businesses might perceive as the development of bad law or bad precedent that could hurt them in subsequent cases. ${ }^{11}$ These legal maneuvers have led scholars to conclude that "Courthouse doors are, for both legal and practical reasons, generally closed to victims, particularly those who live in poverty" (Thompson et al. 2009, p. 895).

The power used by businesses to intimidate, threaten, bribe, and coerce decisions favorable to them is also documented in the business and human rights literature. Working with legal practitioners involved in the prosecution of corporate complicity cases reveals firsthand the threats by business to countersue with libel and slander claims to constrain investigations and public information about the case. Amnesty International and the Inter-American Commission of Human Rights have documented the violence and intimidation indigenous human rights defenders face when they bring claims against extractive and other mega-project firms. ${ }^{12}$ Some groups have proved unwilling to initiate or continue their claims for justice when faced with business threats.

Despite the formidable power of businesses to block accountability for human rights violations, their veto power has not always protected them. Accountability has occurred. In some cases, businesses themselves have contributed to these efforts.

Returning to the industrialist cases, several companies acknowledged their complicity in Nazi regime atrocities. In so doing, they recognized the responsibility of companies to abide by international human rights standards. Deutsche Bahn's historian, for example, put together a "Special Trains to Death" exhibition in the central station acknowledging that "without the Reichsbahn [its predecessor] the industrial murder of millions of people would not have been possible." 13 This recognition occurred without the threat of judicial action. ${ }^{14}$

Compensation funds have offered opportunities for businesses to accept responsibility for past atrocities. These funds may also provide a way for businesses to offset litigation or to improve the company's tarnished image. The German Foundation for Remembrance, Responsibility, and the Future received $\$ 5$ billion contributed equally by the government and industry to compensate surviving forced laborers during World War II. It is not clear how many or which industries made contributions. ${ }^{15}$ Businesses' motivations behind the donations are also not systematically analyzed. Chronologically, these donations did not materialize until after forced laborers initiated lawsuits. Moreover, these contributions sometimes came, as in the case of the Volkswagen fund, with the recognition of "moral responsibility" but denial of "legal responsibility" (Andrews 1998).

\footnotetext{
${ }^{11}$ Settlement outcomes warrant analysis. Although it would appear to be counterproductive for the company's reputation to engage in a long, drawn out court case only to settle in the end, companies may be engaged in long-term battles (future claimants, bad law, bad precedent) rather than short-term cases. A study on US civil claims offers some insights nonetheless (see Albiston 1999).

${ }^{12}$ See particularly the work in Inter-Am. Comm. Hum. Rights 2015.

${ }^{13}$ Suzanne Kill, cited in Connolly 2008.

${ }^{14}$ The 1973 trial of Albert Ganzenmüller, secretary of transport and deputy director of the Reichsbahn, for the firm's involvement in the deportations to death camps was closed after he had a heart attack on the first day. Ganzenmüller lived 23 years after the trial ended without threat of further prosecution.

${ }^{15}$ The American Jewish Committee found 255 corporations that had employed forced labor, and only 17 contributed to the compensation fund (Kempster 1999). Another study mentions 6,300 corporate donations to the compensation fund (Helm 2001). In addition, individual companies, such as Volkswagen and three major Swiss banks, set up independent foundations to pay out compensation (Andrews 1998).
} 
These donations, in other words, have not appeared to weaken veto power or strengthen norms or international law regarding corporate accountability.

Recent attention to corporate complicity in the Argentine dictatorship has provided some evidence that such change is possible, if not likely. The National Stock Exchange created a kind of institutional truth commission to investigate and reveal to the public its complicity in the dictatorship. In another case, a company voluntarily turned over its files to the national prosecutor's office for investigation into human rights abuses. The new owners of the firm presumably hoped to avoid any connection to the past owners and their complicity in the dictatorship.

In sum, although businesses have historically held veto power, greater attention to abuse through civil society mobilization and domestic processes may begin to reduce that power. Judges may find it more objectionable to side with firms publicly exposed for their abusive activity than to rule against them. The more international law recognition of businesses' responsibility for human rights abuses there is, the more difficult it will be for courts to avoid accountability even against powerful businesses.

The current trends are not moving in that direction, however. For the time being, the exposure to business violations is more likely to come from national and international civil society campaigns and not from global institutions. This leads to important conclusions about the direction of causality in enhancing human rights practice.

\section{CONCLUSIONS}

This review seeks to integrate the business and human rights literature with the transitional justice literature. In so doing, it questions the assumptions in both literatures of the importance of international actors and factors in promoting positive human rights practices. The international realm plays a critical role in accountability, yet in the specific area of corporate complicity international human rights law has developed norms and laws that harm, rather than advance, accountability. However, domestic judicial and civil society actors have played a key role in innovating the uses of international human rights law in this area. Indeed, these actors may have become the protagonists in rescuing the normative and legal framework of international human rights law as applied to corporate complicity.

International pressure, domestic judicial leadership, civil society demand, and weak veto players constitute the four factors previously found to overcome impunity and advance accountability for human rights violations. Because of the shift away from Nuremberg Trial applications of international law to corporate complicity, and toward soft-law and voluntary principles, international institutional pressure has remained weak in this area of law. Although transnational advocacy networks have helped local human rights and victims groups to take claims against corporations to foreign courts, the absence of an international judicial forum to hear these cases has limited that interaction. Foreign court venues seem to be shrinking, rather than expanding, in number and scope, as the post-Kiobel ATS suggests.

Indeed, the primary protagonism in the area of corporate accountability for past human rights abuses in dictatorships and armed conflict lies currently with domestic judiciaries and civil society actors. These actors have found legal and social movement innovation capable of overcoming the international legal brake on judicial accountability for past human rights abuses by companies. They have thus also found creative ways from below to overcome the powerful veto role that businesses can play.

These practices have not involved changing law but rather rescuing it from the clutches of international organizations unwilling to apply it to corporate accountability cases. They challenge the acceptance of soft-law and voluntary principles regarding businesses' and states' human rights 
responsibilities and duties. They salvage the Nuremberg theory's "prohibition against aiding and abetting war crimes and other human rights violations ... recognized as customary international law" (Agent Orange case, cited in Skinner 2008, p. 351) and apply it to contemporary cases of corporate complicity in dictatorships and armed conflicts. These practices sometimes involve explicit references to international human rights law but more commonly look for the domestic adaptations of that law.

These efforts are within the grasp of most civil society actors and functional judiciaries. Thus, the innovative strategies explored here could be adapted to other contexts. More scholarly and practitioner focus on diffusion from global to local institutions is not likely to generate better human rights protections in this area of the law. Future research should instead encourage more advocacy-academic dialogue across borders to further develop, refine, and adapt innovative practices that circumvent blocks from international bodies and promote more appropriate local versions of accountability for human rights violations. They may become the Archimedean lever: weak actors who with the right legal instruments can lift the global normative and institutional framework of corporations' human rights responsibilities. ${ }^{16}$

\section{DISCLOSURE STATEMENT}

The authors are not aware of any affiliations, memberships, funding, or financial holdings that might be perceived as affecting the objectivity of this review.

\section{ACKNOWLEDGMENTS}

The authors acknowledge the support for their research from the British Academy, the Open Society Foundation, the John Fell University of Oxford Press Research Fund, and the Economic and Social Research Council's Impact Acceleration Account. They thank Kathryn Babineau, Laura Bernal-Bermúdez, Stephen E. Meili, and Julia Zulver for their assistance on this article. The authors further acknowledge the Corporations and Human Rights Database project, particularly the work by Tricia D. Olsen, in advancing this project. Finally, the authors thank the Corporate Accountability and Transitional Justice project partners for insights into local level initiatives, particularly the Centro de Estudios Legales y Sociales (CELS) and Abogados y Abogadas del Noroeste Argentino en Derecho Humanos y Estudios Sociales (ANDHES) in Argentina and in Colombia the Centro de Estudios de Derecho, Justicia y Sociedad (Dejusticia).

\section{LITERATURE CITED}

Addo M, Martin J. 2016. The evolving business and society landscape: Can human rights make a difference? In The Business and Human Rights Landscape: Moving Forward, Looking Back, ed. J Martin, KE Bravo, pp. 348-83. Cambridge, UK: Cambridge Univ. Press

Albiston C. 1999. The rule of law and the litigation process: the paradox of losing by winning. Law Soc. Rev. 33:869-910

Alford RP. 2014. The future of human rights litigation after Kiobel. Notre Dame Law Rev. 89:1749

Andrews EL. 1998. Volkswagen to create \$12 million fund for Nazi era laborers. New York Times, Sept. 11

Avant DD. 2005. The Market for Force: The Consequences of Privatizing Security. Cambridge, UK: Cambridge Univ. Press

\footnotetext{
${ }^{16}$ Rubens Carvalho Gomes da Silva (2010), in conjunction with his academic supervisor Laurence Whitehead, developed the concept of the Archimedean lever to explain activism in the global South.
} 
Babineau K. 2015. Business as Usual? Transnational Corporations and the Challenge of Human Rights Remedy in Peru. MPhil Thesis, St. Peter's Coll., Lat. Am. Cent., School Interdiscip. Area Stud., Univ. Oxford, Oxford, UK

Balmer JM, Powell SM, Greyser SA. 2011. Explicating ethical corporate marketing. Insights from the BP Deepwater Horizon catastrophe: the ethical brand that exploded and then imploded. F. Bus. Ethics 102(1):1-14

Bernal-Bermúdez L. 2016. The power of corporations and the power of people: understanding remedy and accountability for buman rights violations-Colombia 2000-2014. DPhil thesis in progress, Dep. Sociol., Univ. Oxford (work on file with the authors)

Bilchitz D, Deva S. 2013. The human rights obligations of business: a critical framework for the future. In Human Rights Obligations of Business: Beyond the Corporate Responsibility to Respect, ed. S Deva, D Bilchitz, pp. 1-26. Cambridge, UK: Cambridge Univ. Press

Block F. 1984. The ruling class does not rule: notes on the Marxist theory of the state. In The Political Economy: Reading in the Politics and Economics of American Public Policy, ed. T Ferguson, J Rogers. Armonk, NY: M.E. Sharpe

Boadle A, Winter B. 2014. Brazil dictatorship probe urges prosecuting military, companies. Reuters, Dec. 10

Bohoslavsky JP. 2012. El eslabón financiero en la justicia transicional Uruguaya. Rev. Urug. Cienc. Polit. 21(2):153-79

Bohoslavsky JP, Opgenhaffen V. 2010. Past and present of corporate complicity: financing the Argentinean dictatorship. Harvard Hum. Rights 7. 23:157-203

Bohoslavsky JP, Rulli M. 2010. Corporate complicity and finance as a "killing agent": the relevance of the Chilean case. 7. Int. Crim. Fustice 8(3):829-50

Bohoslavsky JP, Torelly MD. 2014. Financial complicity: the Brazilian dictatorship under the "macroscope." In fustice and Economic Violence in Transition, ed. DN Sharp, pp. 233-62. New York: Springer

Brant M. 2013. Projeto Adeus Boilesen. YouTube video, June 13. https://www.youtube.com/watch?v= SDM-PXdAS2w

Bueno de Mesquita B, Cohen LE. 1995. Self-interest, equity, and crime control: a game-theoretic analysis of criminal decision making. Criminology 33:483-518

Buhman K. 2013. Navigating from "train wreck" to being "welcomed": negotiation strategies and argumentative patterns in the development of the UN Framework. In Human Rigbts Obligations of Business: Beyond the Corporate Responsibility to Respect, ed. S Deva, D Bilchitz, pp. 29-57. Cambridge, UK: Cambridge Univ. Press

Carvalho Gomes da Silva R. 2010. Values, knowledge and activism in the Brazilian Amazon: from the boomerang to the Archimedean lever. MSc ext. essay, Oriel Coll., Lat. Am. Cent., School Interdiscip. Area Stud., Univ. Oxford, Oxford, UK

Černič JL. 2016. Corporate accountability for human rights: from a top-down to a bottom-up approach. In The Business and Human Rights Landscape: Moving Forward, Looking Back, ed. J Martin, KE Bravo, pp. 193-218. Cambridge, UK: Cambridge Univ. Press

Chesterman S. 2004. Oil and water: regulating the behavior of multinational corporations through law. N.Y. Univ. 7. Int. Law Polit. 36:307-29

Chevron Corp. v. Naranjo, 133 S.Ct. 423 (2012)

Clapham A. 2000. The question of jurisdiction under international criminal law over legal persons: lessons from the Rome Conference on an international criminal court. In Liability of Multinational Corporations under International Law, ed. MT Kamminga, S Zia-Zarifi, pp. 139-95. The Hague, Neth.: Kluwer Law Int.

Clapham A. 2008. Extending international criminal law beyond the individual to corporations and armed opposition groups. F. Int. Crim. Fustice 6(5):899-926

Colvin C. 2006. Overview of the reparations program in South Africa. In The Handbook of Reparations, ed. P De Greiff, pp. 176-214. Oxford: Oxford Univ. Press

Connolly K. 2008. German railways admits complicity in Holocaust. The Guardian, Jan. 23. http://www. theguardian.com/world/2008/jan/23/secondworldwar.germany

Cooper N. 2002. State collapse as business: the role of conflict trade and the emerging control agenda. Dev. Change 33(5):935-55 
Dandan A, Franzki H. 2013. Entre analisis historico y responsabilidad juridica. See Vertbisky \& Bohoslavsky 2013, pp. 217-34

Danner AM. 2005. Nuremberg industrialist prosecutions and aggressive war. Va. 7. Int. Law 46:651

Davis M. 2003. The Pinochet Case: Origins, Progress and Implications. London: Univ. London

Deitelhoff N, Feil M, Fischer S, Haidvogl A, Wolf DK, Zimmer M. 2010. Business in zones of conflict and global security governance: What has been learnt and where to from here? In Corporate Security Responsibility?, ed. N Deitelhoff, K Wolf, pp. 202-26. Glob. Issues Ser. London: Palgrave Macmillan

Dougherty C. 2011. Introduction to Econometrics. Oxford: Oxford Univ. Press

Downs GW, Rocke DM, Barsoom PN. 1996. Is the good news about compliance good news about cooperation? Int. Organ. 50(03):379-406

Felstiner WLF, Abel RL, Sarat A. 1981. The emergence and transformation of disputes: naming, blaming, claiming. Law Soc. Rev. 15:631-54

Ford J. 2015. Regulating Business for Peace. Cambridge, UK: Cambridge Univ. Press

Friedman EJ. 1999. The effects of transnationalism reversed in Venezuela: assessing the impact of UN global conferences on the women's movement. Int. Fem. F. Polit. 1(3):357-81

Gualde A. 2013. El Caso Papel Prensa. See Vertbisky \& Bohoslavsky 2013, pp. 345-60

Halliday TC, Carruthers BG. 2007. The recursivity of law: global norm-making and national law-making in the globalization of corporate insolvency regimes. Am. F. Sociol. 112(4):1135-202

Hathaway OA. 2002. Do human rights treaties make a difference? Yale Law F. 111:1935-2042

Haufler V. 2010. Disclosure as governance: the extractive industries transparency initiative and resource management in the developing world. Glob. Environ. Polit. 10(3):53-73

Helm T. 2001. Germany to compensate Nazi slave labourers. Telegraph, May 31

Heyer AKD. 2012. Corporate complicity under international criminal law: a case for applying the Rome Statute to business behaviour. Hum. Rights Int. Leg. Discourse 6:14

Horrigan B. 2010. Corporate Social Responsibility in the 21st Century: Debates, Models and Practices across Government, Law and Business. Cheltenham, UK: Edward Elgar

Hutto C, Jenkins A. 2010. Report on corporate complicity litigation in the Americas: leading doctrines, relevant cases, and analysis of trends. Rep., Hum. Rights Clin., Univ. Tex., Austin, TX. https://law.utexas. edu/wp-content/uploads/sites/11/2015/04/2010-HRC-Report-CorporateComplicity.pdf

Int. Comm. Jurists. 2008. Report of the ICf Expert Legal Panel on Corporate Complicity in International Crimes. Geneva: Int. Comm. Jurists

Inter-Am. Comm. Hum. Rights. 2015. Situación de derechos humanos de defensores y defensoras del medio ambiente en el contexto de las industrias extractivas en América. Human Rights Brief, Oct. 19. http:// hrbrief.org/2015/10/situacion-de-derechos-humanos-de-defensores-y-defensoras-del-medioambiente-en-el-contexto-de-las-industrias-extractivas-en-america/

Ite UE. 2004. Multinationals and corporate social responsibility in developing countries: a case study of Nigeria. Corp. Soc. Responsib. Environ. Manag. 11(1):1-11

Joseph S. 2000. An overview of the human rights accountability of multinational enterprises. In Liability of Multinational Corporations Under International Law, ed. MT Kamminga, S Zia-Zarifi, pp. 75-93. The Hague, Neth.: Kluwer Law Int.

Karp DJ. 2014. Responsibility for Human Rights: Transnational Corporations in Imperfect States. Cambridge, UK: Cambridge Univ. Press

Keck ME, Sikkink K. 1998. Activists beyond Borders: Advocacy Networks in International Politics. Cambridge, UK: Cambridge Univ Press

Kelly MJ. 2012. Prosecuting corporations for genocide under international law. Harvard Law Policy Rev. 6:339-67

Kempster N. 1999. Agreement reached on Nazi slave reparations. War: Tentative accord between U.S. and Germany would provide $\$ 5.2$ billion for those forced to labor during WWII. Los Angeles Times, Dec. 15, pp. A1-2

Khulumani v. Barclay National Bank Ltd., 509 F.3d 148 2d Cir. (2007)

Kiobel v. Royal Dutch Petroleum Co., 133 S. Ct. 1659 (2013)

Laufer WS. 2003. Social accountability and corporate greenwashing. 7. Bus. Ethics 43(3):253-61 
Levit JK. 2007. Bottom-up international lawmaking: reflections on the New Haven School of International Law. Yale 7. Int. Law 32:2008-3

Lim A, Tsutsui K. 2012. Globalization and commitment in corporate social responsibility cross-national analyses of institutional and political-economy effects. Am. Sociol. Rev. 77(1):69-98

Lindblom C. 1977. Politics and Markets: The World's Political-Economic Systems. New York: Basic Books

Liu S, Halliday TC. 2009. Recursivity in legal change: lawyers and reforms of China's criminal procedure law. Law Soc. Inq. 34(4):911-50

Lutz EL, Reiger C. 2009. Prosecuting Heads of State. Cambridge, UK: Cambridge Univ. Press

Maassarani TF. 2005. Four counts of corporate complicity: alternative forms of accomplice liability under the Alien Tort Claims Act. N.Y. Univ. 7. Int. Law Polit. 38:39-65

Madami D. 1999. A review of the role and impact of export processing zones. Policy Res. Work. Pap., World Bank, Washington, DC

Mantilla G. 2009. Emerging international human rights norms for transnational corporations. Glob. Gov. Rev. Multilater. Int. Organ. 15(2):279-98

Martin J, Bravo KE. 2016. The Business and Human Rights Landscape: Moving Forward, Looking Back. Cambridge, UK: Cambridge Univ. Press

McCarthy B. 2002. New economics of sociological criminology. Annu. Rev. Sociol. 28:417-42

Michalowski S. 2014. Corporate Accountability in the Context of Transitional fustice. Abingdon, UK: Routledge

Miliband R. 1969. The State in Capitalist Society. New York: Basic Books

Mills CW. 1956. The Power Elite. Oxford: Univ. Oxford Press

Moran M. 2002. Misunderstanding of the regulatory state? Br. 7. Polit. Sci. 32:391-413

Mwangi W, Rieth L, Schmitz HP. 2013. Encouraging greater compliance: local networks and the United Nations Global Compact. In The Persistent Power of Human Rights: From Commitment to Compliance, ed. T Risse, SC Ropp, K Sikkink, pp. 203-21. Cambridge, UK: Cambridge Univ. Press

Nagin DS. 1998. Criminal deterrence research at the outset of the twenty-first century. Crime fustice 23:1-42

Narine ML. 2016. Living in a material world-from naming and shaming to knowing and showing: Will new disclosure regimes finally drive corporate accountability for human rights? In The Business and Human Rights Landscape: Moving Forward, Looking Back, ed. J Martin, KE Bravo, pp. 219-53. Cambridge, UK: Cambridge Univ. Press

Neumayer E. 2005. Do international human rights treaties improve respect for human rights? F. Confl. Resolut. 49(6): $925-53$

Nolan J. 2013. The corporate responsibility to respect human rights: Soft law or not law? In Human Rights Obligations of Business: Beyond the Corporate Responsibility to Respect, ed. S Deva, D Bilchitz, pp. 138-61. Cambridge, UK: Cambridge Univ. Press

O'Donnell GA. 1973. Modernization and Bureaucratic-Authoritarianism: Studies in South American Politics. Polit. Mod. Ser. Berkeley: Inst. Int. Stud., Univ. Calif.

Offe C, Wiesenthal H. 1980. Two logics of collective action: theoretical notes on social class and organizational form. Polit. Power Soc. Theory 1:67-115

Paul G, Schönsteiner J. 2013. Transitional justice and the UN guiding principles on business and human rights. In Corporate Accountability in the Context of Transitional fustice, ed. S Michalowski, pp. 73-92. Abingdon, UK: Routledge

Payne LA. 1994. Brazilian Industrialists and Democratic Change. Baltimore, MD: Johns Hopkins Univ. Press

Payne LA. 2013. Cumplicidade empresarial na ditadura brasileira. $10^{a}$ Revista Anistia: Cooperação Econômica com a Ditadura, July/Dec.

Payne LA. 2014. The justice paradox? Transnational legal orders and accountability for past human rights violations. In Transnational Legal Orders, ed. TC Halliday, G Shaffer, pp. 439-74. Cambridge, UK: Cambridge Univ. Press

Payne LA, Lessa F, Pereira G. 2015. Overcoming barriers to justice in the age of human rights accountability. Hum. Rights Q. 37(3):728-54

Payne LA, Pereira G. 2015. Accountability for corporate complicity in human rights violations: Argentina's transitional justice innovation? In The Economic Accomplices to the Argentine Dictatorship: Outstanding Debts, ed. JP Bohoslavsky, H Verbitsky, pp. 29-46. Cambridge, UK: Cambridge Univ. Press 
Payne LA, Pereira G. 2016. La complicidad corporativa en las violaciones de derechos humanos: ¿una innovación de la justicia transicional en Argentina? In Los derechos humanos y las empresas: Reflexiones desde América Latina, ed. H Cantú Rivera. San José, Costa Rica: IIDH

Popova A. 2016. Business and human rights after Ruggie's mandate: feasible next steps. In The Business and Human Rights Landscape: Moving Forward, Looking Back, ed. J Martin, KE Bravo, pp. 106-144. Cambridge, UK: Cambridge Univ. Press

Porter ME, Kramer MR. 2006. Strategy and society. Harvard Bus. Rev. 84(12):78-92

Poulantzas N. 1968. Political Power and Social Classes. London, UK: Verso Ed.

Red Card Campaign. 2010. Farewell Germany ... but what about Daimler? Khulamani Red Card Campaign Blog, July 8. https://redcardcampaign.wordpress.com/2010/07/08/farewell-germany-but-whatabout-daimler/

Reno W. 1997. African weak states and commercial alliances. Afr. Aff. 96(383):165-86

Risse T, Ropp SC. 2013. Introduction and overview. In The Persistent Power of Human Rights: From Commitment to Compliance, ed. T Risse, SC Ropp, K Sikkink, pp. 3-25. Cambridge, UK: Cambridge Univ. Press

Roht-Arriaza N. 2005. The Pinochet Effect: Transnational fustice in the Age of Human Rights. Philadelphia: Univ. Pa. Press

Roht-Arriaza N. 2013. ¿Por qué la dimensión económica estuvo ausente tanto tiempo en la justicia transicional? Un ensayo exploratorio. See Vertbisky \& Bohoslavsky 2013, pp. 31-43

Roht-Arriaza N. 2015. Why was the economic dimension missing for so long in transitional justice? An exploratory essay. In The Economic Accomplices to the Argentine Dictatorship: Outstanding Debts, ed. JP Bohoslavsky, H Verbitsky, pp. 19-28. Cambridge, UK: Cambridge Univ. Press

Ruggie J. 2013. Fust Business: Multinational Corporations and Human Rights. New York: W.W. Norton

Ruggie JG. 2014. Global governance and "new governance theory": lessons from business and human rights. Glob. Gov. 20(1):5-17

Sagafi-Nejad T, Dunning JH. 2008. The UN and Transnational Corporations: From Code of Conduct to Global Compact. Bloomington: Indiana Univ. Press

Schabas WA. 2005. War economies, economic actors, and international criminal law. In Profiting from Peace: Managing the Resource Dimensions of Civil War, ed. K Ballentine, H Nitzschke, pp. 425-43. Boulder, CO: Lynne Reinner

Sharp D. 2013. Interrogating the peripheries: the preoccupations of fourth generation transitional justice. Harvard Hum. Rights 7. 26:149-78

Sharp D, ed. 2014. Fustice and Economic Violence in Transition. New York: Springer

Sikkink K. 2011. The Justice Cascade: How Human Rights Prosecutions Are Changing World Politics. Norton Ser. World Polit. New York: W.W. Norton

Skinner G. 2008. Nuremberg's legacy continues: the Nuremberg Trials' influence on human rights litigation in US courts under the Alien Tort Statute. Albany Law Rev. 71(1):321-67

Skocpol T, Somers M. 1980. The uses of comparative history in macrosocial inquiry. Comp. Stud. Soc. Hist. 22(2):174-97

Stanley W. 1996. The Protection Racket State: Elite Politics, Military Extortion, and Civil War in El Salvador. Philadelphia: Temple Univ. Press

Stephens B. 2000. Corporate accountability: international human rights litigation against coprorations in US courts. In Liability of Multinational Corporations Under International Law, ed. MT Kamminga, S Zia-Zarifi, pp. 209-29. The Hague, Neth.: Kluwer Law Int.

Stewart JG. 2014. Turn to corporate criminal liability for international crimes: transcending the Alien Tort Statute. N.Y. Univ. 7. Int. Law Polit. 47:121

Sunstein CR. 1996. Social norms and social roles. Columbia Law Rev. 96:903-68

Teitel RG. 2000. Transitional Fustice. Oxford: Oxford Univ. Press

Thompson G. 2013. South Africa to pay $\$ 3,900$ to each family of apartheid victims. New York Times, April 16. http://www.nytimes.com/2003/04/16/world/south-africa-to-pay-3900-to-each-familyof-apartheid-victims.html

Thompson RC, Ramasastry A, Taylor M. 2009. Translating Unocal: the expanding web of liability for business entities implicated in international crimes. George Wash. Int. Law Rev. 40(4):841-902 
Tófalo I. 2006. Overt and hidden accomplices: transnational corporations' range of complicity in human rights violations. In Transnational Corporations and Human Rights, ed. O de Schutter, pp. 335-58. Oxford: Hart van der Wilt H. 2013. Corporate criminal responsibility for international crimes: exploring the possibilities. Chin. 7. Int. Law 12(1):43-77

Verbitsky H, Bohoslavsky JP. 2013. Cuentas pendientes: Los cómplices económicos de la dictadura. Buenos Aires: Siglo Veintiuno

Verbitsky H, Bohoslavsky JP. 2015. The Economic Accomplices to the Argentine Dictatorship: Outstanding Debts. Cambridge, UK: Cambridge Univ. Press

Vest H. 2010. Business leaders and the modes of individual criminal responsibility under international law. 7. Int. Crim. Fustice 8(3):851-72

Vogel D. 1978. Why businessmen distrust their state: the political consciousness of American corporation executives. Br. F. Polit. Sci. 8:45-78

Vogel D. 1983. The power of business in America: a re-appraisal. Br. F. Polit. Sci. 13(1):19-43

Wawryk A. 2003. Regulating transnational corporations through corporate codes of conduct. In Transnational Corporations and Human Rights, ed. JG Frynas, S Pegg, pp. 53-78. New York: Springer

Weissbrodt D, Kruger M. 2005. Human rights responsibilities of businesses as non-state actors. In Non-State Actors and Human Rights, ed. P Alston, pp. 315-49. Oxford: Oxford Univ. Press

Wiesen SJ. 2000. German industry and the Third Reich: fifty years of forgetting and remembering. Dimensions $13(2)$

Wolf KD, Deitelhoff N, Engert S. 2007. Corporate security responsibility towards a conceptual framework for a comparative research agenda. Coop. Confl. 42(3):294-320

Wouters J, Ryngaert C. 2009. Impact on the process of the formation of customary international law. In The Impact of Human Rights Law on General International Law, ed. MT Kamminga, M Scheinin, pp. 111-31. Oxford: Oxford Univ. Press

Zerk J. 2014. Corporate Liability for Gross Human Rights Abuses: Towards a Fairer and More Effective System of Domestic Law Remedies. Geneva: UN High Comm. Hum. Rights 